\title{
"Impulse buying behavior among female shoppers: Exploring the effects of selected store environment elements"
}

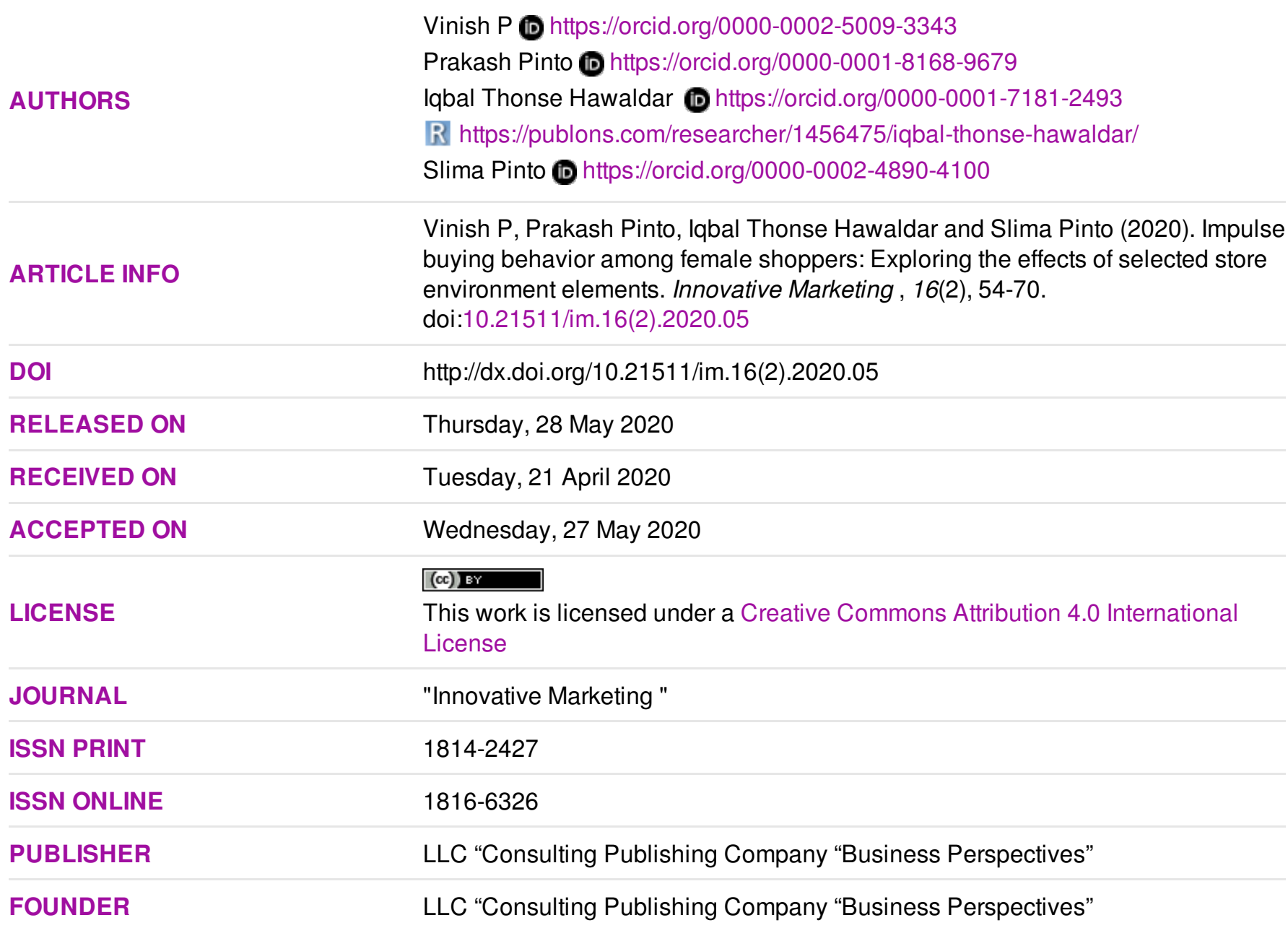

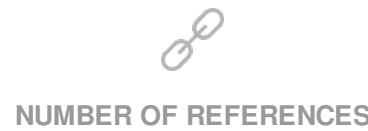

96
NUMBER OF FIGURES

0
NUMBER OF TABLES

20

(C) The author(s) 2023. This publication is an open access article. 


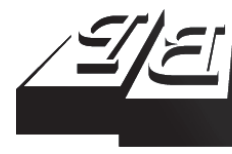

\section{BUSINESS PERSPECTIVES}

(O)

LLC "CPC "Business Perspectives" Hryhorii Skovoroda lane, 10, Sumy, 40022, Ukraine www.businessperspectives.org
Received on: $21^{\text {st }}$ of April, 2020 Accepted on: $27^{\text {th }}$ of May, 2020 Published on: $28^{\text {th }}$ of May, 2020

(C) Vinish P, Prakash Pinto, Iqbal Thonse Hawaldar, Slima Pinto, 2020

Vinish P, Assistant Professor, Department of Business Administration, St Joseph Engineering College Mangaluru, Karnataka, India.

Prakash Pinto, Ph.D., Professor and Dean, Department of Business Administration, St Joseph Engineering College Mangaluru, Karnataka, India.

Iqbal Thonse Hawaldar, Ph.D., Professor, Department of Accounting and Finance, College of Business Administration, Kingdom University, Bahrain. (Corresponding author)

Slima Pinto, Research Scholar, Department of Business Administration, St Joseph Engineering College Mangaluru, Karnataka, India.

This is an Open Access article, distributed under the terms of the Creative Commons Attribution 4.0 International license, which permits unrestricted re-use, distribution, and reproduction in any medium, provided the original work is properly cited.

Conflict of interest statement: Author(s) reported no conflict of interest

Vinish P (India), Prakash Pinto (India), Iqbal Thonse Hawaldar (Bahrain), Slima Pinto (India)

\title{
IMPULSE BUYING BEHAVIOR AMONG FEMALE SHOPPERS: EXPLORING THE EFFECTS OF SELECTED STORE ENVIRONMENT ELEMENTS
}

\begin{abstract}
This paper intends to analyze the impact of store layout, ambient factors, and employees on impulsive decision-making among female customers visiting the apparel outlets. The responses were collected through a single-stage mall intercept survey method using a structured questionnaire from 385 respondents in leading apparel stores in selected Tier I and Tier II cities in the state of Karnataka, India. The responses were analyzed using multiple regression analysis. Constructs such as store layout, ambience and employees were found to be significantly positively correlated with impulse buying behavior. The variables largely explain the variation in impulse buying under store ambiance. Except 'attention to the window display' and 'friendly staff' all other twelve variables considered in the study were found to have significant impact on the impulse buying behavior. Though store ambiance, well-structured layout, and pleasant shopping experience are essential determinants of customer satisfaction, the study results imply that the number of store staff and sales skills are critical aspects of impulse buying in the apparel business and true assets to the retail organization. Additionally, poor customer interaction, staff shortage, and high employee attrition could discourage the store's revenue generation.
\end{abstract}

Keywords

JEL Classification

\section{INTRODUCTION}

Impulse buying is a widely acknowledged phenomenon in retail research (Stern, 1962; Bellenger et al., 1978; Hoch \& Loewenstein, 1991; Mattila \& Wirtz, 2008; Badgaiyan \& Verma, 2014; Cakanlar \& Nguyen, 2019). A considerable amount of money is spent on marketing activities at retail stores to increase product familiarity, trail, and eventually increase the market share (Zhou \& Wong, 2003). Men and women are equally susceptible to impulsive buying, but women are more subjected to post-purchase dissonance (Pandey, 2018). Previous research indicates that women and men distinctly relate to their material possessions (Dittmar, Beattie, \& Friese, 1995). Men favor the objects that are of functional importance and denote personal accomplishments, while women tend to articulate social ties and value symbolic possessions (Adler, Csikszentmihalyi, \& Rochberg-Halton, 1983; Wallendorf \& Arnould, 1988).

The literature on impulse buying demoed the effect of situational factors in various shopping situations (Amos, Holmes, \& Keneson, 2014; Badgaiyan \& Verma, 2015). Store attributes such as lighting (Summers \& Hebert, 2001), music (Dube \& Morin, 2001; Chang et al., 2014), and 
scent (Mattila \& Wirtz, 2001) better display sensory stimuli and positive social influence (Amos et al., 2014), pricing and product characteristics (Kacen, Hess, \& Walker, 2012; Muratore, 2016; Hawaldar, Ullal, Birau, \& Spulbar, 2019) influence the holistic perception of servicescape and subsequent impulse buying decisions. However, the above studies have concentrated on American and European countries. The research shows that the consumption patterns of society, such as fashion, grooming, food, gifting, are subject to its culture (Schiffman \& Wisenblit, 2015; Ullal \& Hawaldar, 2018). Few studies have documented the impact of situational factors and intrinsic factors on impulse buying in Central India (Badgaiyan \& Verma, 2014, 2015; Atulkar \& Kesari, 2017). However, these studies are not gender-specific and addressed shoppers in general visiting supermarkets, hypermarkets, or shopping malls. Mitchell and Potenza (2015) suggested studying the "gender differences in addictions and impulsivity and their interactions". Moreover, apparel has often been quoted as a product category having product involvement, complexity, and uncertainty (Bloch, 1986; Goldsmith \& Emmert, 1991; Kim, 2005; Radder \& Huang, 2008).

With a higher number of women being the part of the workforce, and easy access to credit and discretionary income, retailers can't disregard the buying power of Indian women shoppers. Today's women are increasingly well informed about the multitude of brands, retailer services and are more demanding than ever. Hence, this study aims to understand the impulse buying behavior of female shoppers, specifically in the context of apparel retailing. In addition to making a significant contribution to the knowledge base, the study will aid the retailers to modulate the store environment and in-store service by understanding the women consumers' behavior.

\section{LITERATURE REVIEW}

Consumers buy apparel to communicate their value to others and, thus, are connected with the emotions (Kaiser, 1997; Kim, 2005). According to PTI Report (2019b), "The Indian apparel market, pegged at around USD 65 billion, is the second-largest retail market after food \& grocery in India". Varying demographic characteristics, rising disposable income, changing taste of shoppers are compelling reasons for the growth of the organized retail industry (IBEF, 2019). The domestic apparel market is "expected to grow at nearly 11 percent CAGR in 2017-2021 period to reach a value of USD 85 billion by 2021" (PTI, 2019). The store layout, visual merchandising, brand availability, and loyalty points are important determinants for the choice of the apparel store (Prakash, Sahney, Kodati, \& Shrivastava, 2017).

Store atmosphere can be explained as "an effort to design buying environments to produce specific emotional effects in the buyer that enhance his purchase probability" (Kotler, 1974). Prior research has examined the effects of in-store factors on the shopping experience and behavioral intentions such as background music (Milliman, 1986; Gopal, 2010; Morrison et al., 2011; Santos \& Freire,
2013), lighting (Baker, Levy, \& Grewal, 1992; Areni \& Kim, 1994; Lin \& Yoon, 2015), color (Bellizzi \& Hite, 1992; Brengman, 2002), and store layout (Liu, Melara, \& Arangarasan, 2007; V. Nirushan \& K. Nirushan, 2017). Mattila and Wirtz (2008) deliberated the role of environmental factors in stimulating impulse purchases in a retail setting. Badgaiyan and Verma (2014) detailed the effect of intrinsic factors such as personality, impulse buying tendency, culture, materialism, and shopping enjoyment tendency on impulse buying behavior. Sharma, Sivakumaran, and Marshall (2010) established a positive association between consumer impulsiveness, optimum stimulation level and impulse buying and variety-seeking behavior. Herabadi, Verplanken, and Van Knippenberg (2009) argued in favor of hedonistic considerations of the shoppers offering a cognitive facet driving impulse purchase. A subsequent study by Sharma et al. (2014) indicates consumer impulsiveness as an outcome of the "three-dimensional construct consisting of cognitive, affective, and behavioral dimensions". Floh and Madlberger (2013) observed the significance of atmospheric cues such as store design, navigation, and content, on shopping enjoyment, and, ultimately, impulse buying behavior in the context of online stores. The study results suggested that attributes such as store de- 
sign and navigation have a substantial impact on shopping enjoyment, while the in-store content did not have any effect. Undoubtedly, store atmosphere influences the store image and shoppers' attitude towards it (Chang et al., 2014).

\subsection{Store layout}

Modern consumers are increasingly seeking superior in-store experience as against product experience (Moore, 2006). The store layout boosts a positive shopping environment and consumer behavioral intentions (Lewison, 1994; Ullal \& Hawaldar, 2018). Retail shelves, a key aspect of store layout, when designed efficiently, play a pivotal role in higher shopper satisfaction and improved relationships (Hwang, Choi, \& Lee, 2005). Personal space acts as an impetus for the shopping experience. Besides, it influences the actual choices made inside the retail store (Bitner, 1992; Turley \& Milliman, 2000; Ullal et al., 2020). The space between the objects can affect customer emotions and decisions (Williams \& Bargh, 2008; Hawaldar et al. 2019). There is a tendency to approach or avoid the product or store (Singh et al., 2014). Levav and Zhu (2009) showed a positive correlation between perceived space (between the aisle) and their buying choices. Donovan et al. (1994) suggest that the store atmosphere's pleasure entices the shoppers to spend more time and money in the outlet than planned. Further, the result would vary according to the retail store, such as a grocery store and apparel outlet. Apparel stores predominantly follow the freeform layout (Lewison, 1994; Vrechopoulos, O'Keefe, Doukidis, \& Siomkos, 2004). Therefore, the study presumes the freeflow store layout to have a constructive effect on impulse buying among female customers. The discussion leads us to the following hypothesis:

\section{H1: The freeflow store layout encourages impulse buying behavior among female customers in apparel stores.}

\subsection{Store ambiance}

The store environment is made of store design, lighting, color, air quality, music, and decoration (Yoo, Park, \& MacInnis, 1998; Cottet, Lichtle, \& Plichon, 2010), and the atmosphere persuades positive emotions and in-store customer behav- ior (Lai \& Chang, 2015; Ju \& Ahn, 2016). Music is an easily controllable element of the atmosphere by way of varying the tempo and, hence, is an attractive ambient factor (Ding \& Lin, 2012). Customers seemingly make an impulse purchase when fast music is played in the store (Ma, $\mathrm{Liu}, \mathrm{Li}$, \& Chen, 2017).

Colors in the store environment have perceptual attributes that affect the customer's perception and attract footfalls towards a retail display (Bellizzi, Crowley, \& Hasty, 1983). Further, it can drive purchase intentions and actual behavior (Bellizzi \& Hite, 1992). Warmer colors are affiliated with physiological stimulation (Gerard, 1958) and elated mood states (Schaie \& Heiss, 1964; Bellizzi \& Hite, 1992). Paradoxically, retail stores having warmer colors are usually unpleasant, while cooler colors are perceived as pleasant (Bellizzi \& Hite, 1992).

Lighting, visual merchandising, and display fixtures significantly contribute to store atmosphere in Indian retail stores (Singh, Katiyar, \& Verma, 2014). Well-planned lighting designs are a boon for store interiors and can help in gaining customer attention to merchandise, sales promotion, and create shopping pleasure (Smith, 1989). Lighting and music jointly induce a pronounced effect on customers' in-store emotions (Yoo et al., 1998). Customers visiting the retail store perceive layout, lighting, music, and staff as a unified world and attribute it to the store environment (Mohan, Sivakumaran, \& Sharma, 2013). Further, in-store factors such as lighting, background music, and staff interaction were significantly correlated with the shopping enjoyment tendency, which, in turn, enhanced the impulse buying tendency (Mohamad, 2015; Ullal, Hawaldar, Mendon, \& Joesph, 2020). Iberahim, Zureena, Adila, and Quraisyiah, (2018) concluded that "to a certain degree, in a chaotic shopping environment, floor merchandising and lightings are less likely to affect impulse buying behavior", and suggested further investigation on the relevance of antecedents in the "fashion industry, in other locations, and/or types of stores". This leads to the following hypothesis:

H2: Attractive store ambiance leads to impulse buying behavior among female customers in apparel stores. 


\subsection{Store employees}

Bitner (1990) advocates that employee behavior contributes to shopper evaluations. Crawford and Melewar (2003) contend that the store staff's presence in a store influences impulse buying. Employees provide product guidance, answer the queries by which customer frustration is reduced during the buying process (Parboteeah, 2005; Virvilaite, Saladiene, \& Bagdonaite, 2009; Yu \& Bastin, 2010; Husnain, Rehman, Syed, \& Akhtar, 2019). Customers who received good quality service from the store sales personnel displayed higher impulse buying and revisited the intentions than those who received poor quality service (Pornpitakpan, Yuan, \& Han, 2017). The sales conversion rate increased by half when the salesperson initiated contact with the customers who visited apparel stores (Underhill, 2009). Customers' perception of the store crowding and employee friendliness collectively impact the impulse buying decisions (Mattila \& Wirtz, 2008). Atulkar and Kesari (2017) noticed higher footfalls in retail stores during weekends and holidays with a larger number of families, thus, prompting impulse buying. Husnain et al. (2019) showed a positive relationship between family influence, time availability, and impulse buying behavior among generation Y consumers. Luo (2005) argued that the presence of peers in the store enhances the desire for impulse buying, while family reduces it. Oliver and Swan (1989) opined that the salesperson's conduct and actions could impact customer satisfaction. Accordingly, the study proposes the following hypothesis:

H3: Store employees' interaction with female customers positively influences their impulse buying behavior.

\section{RESEARCH METHODOLOGY}

\subsection{Sample designing and data collection}

According to MSME-Development Institute (2016), Karnataka is "one of the most progressive and industrialized states in the country and a leading state in driving India's economic growth". It is the IT capital of India, with exports more than USD
60 billion and is the $4^{\text {th }}$ largest technology cluster in the world (IBEF, 2018). In terms of Human Development Index, the state shares the nineteenth rank (Global Data Lab, 2019) in the country. The NASSCOM-AT Kearney Report (2017) has identified four major cities in Karnataka viz. Bengaluru (leader location), Mangaluru (challenger location), Hubballi-Dharwad, and Mysuru (aspirant location) for its business potential. The study, therefore, considered a sample of 385 female customers (convenience sampling method) visiting the leading apparel stores such as Max, Central, Westside, and Pantaloons in leading Tier I (Bengaluru) and Tier II (Mangaluru, Mysuru, Hubballi-Dharwad) cities in the state of Karnataka, India.

The selected stores have a pan-Indian presence, offering a wide range of branded merchandise for all age groups. Moreover, the stores have a unique layout, choice of music, colors, unique dress code, trained staff and are intended to encourage customers' emotions and purchase behaviour. The study followed a single-stage mall intercept survey method to gather responses, much like earlier studies (e.g., Beatty \& Ferrell, 1998; Sharma et al., 2010; Mohan et al., 2013).

\subsection{Measurement instrument}

The study explores the influence of store layout, ambient factors, and human factors on the impulse buying behavior among female customers. Existing scales in the relevant literature were adapted to measure the constructs, store layout (Mihic \& Kursan, 2010; Mohan et al., 2013; Badgaiyan \& Verma, 2014), store ambiance (Mattila \& Wirtz, 2008; Mihic \& Kursan, 2010; Mohan et al., 2013; Atulkar \& Kesari, 2018), store employees (Mihic \& Kursan, 2010; Mohan et al., 2013), urge to buy spontaneously (Beatty \& Ferrell, 1998; Pradhan, 2016), and money spent (Beatty \& Ferrell, 1998; Pradhan, 2016).

\subsection{Convergent and discriminant validity}

Convergent and discriminant validities are two important facets of construct validity. Convergent validity shows how the new scale is related to other variables and other measures of the same construct. The discriminant validity presents the construct 
Table 1. Correlation between the variables of store layout

\begin{tabular}{|c|c|c|c|c|c|c|c|}
\hline $\begin{array}{c}\text { Variables: Store } \\
\text { Layout }\end{array}$ & & $\begin{array}{c}\text { Well- } \\
\text { structured } \\
\text { layout }\end{array}$ & $\begin{array}{c}\text { Pleasing } \\
\text { store decor }\end{array}$ & $\begin{array}{c}\text { Attractive } \\
\text { display }\end{array}$ & $\begin{array}{c}\text { Pay } \\
\text { attention to } \\
\text { the window } \\
\text { display }\end{array}$ & $\begin{array}{c}\text { Creative and } \\
\text { systematic } \\
\text { arrangement of } \\
\text { products }\end{array}$ & $\begin{array}{l}\text { Comfortable } \\
\text { and well- } \\
\text { maintained } \\
\text { trial rooms }\end{array}$ \\
\hline \multirow{3}{*}{$\begin{array}{l}\text { Well-structured } \\
\text { layout }\end{array}$} & Pearson correlation & 1 & $0.518^{* *}$ & $0.632^{* *}$ & $0.521^{* *}$ & $0.598^{* *}$ & $0.525^{* *}$ \\
\hline & Sig. (2-tailed) & & 0.000 & 0.000 & 0.000 & 0.000 & 0.000 \\
\hline & N & 385 & 385 & 385 & 385 & 385 & 385 \\
\hline \multirow{3}{*}{ Pleasing store decor } & Pearson correlation & $0.518^{* *}$ & 1 & $0.466^{* *}$ & $0.750^{* *}$ & $0.526^{* *}$ & $0.576^{* *}$ \\
\hline & Sig. (2-tailed) & 0.000 & & 0.000 & 0.000 & 0.000 & 0.000 \\
\hline & $N$ & 385 & 385 & 385 & 385 & 385 & 385 \\
\hline \multirow{3}{*}{ Attractive display } & Pearson correlation & $0.632^{* *}$ & $0.466^{* *}$ & 1 & $0.548^{* *}$ & $0.670^{* *}$ & $0.574^{* *}$ \\
\hline & Sig. (2-tailed) & 0.000 & 0.000 & & 0.000 & 0.000 & 0.000 \\
\hline & N & 385 & 385 & 385 & 385 & 385 & 385 \\
\hline \multirow{3}{*}{$\begin{array}{l}\text { Pay attention to the } \\
\text { window display }\end{array}$} & Pearson correlation & $0.521^{* *}$ & $0.750^{* *}$ & $0.548^{* *}$ & 1 & $0.473^{* *}$ & $0.656^{* *}$ \\
\hline & Sig. (2-tailed) & 0.000 & 0.000 & 0.000 & & 0.000 & 0.000 \\
\hline & $N$ & 385 & 385 & 385 & 385 & 385 & 385 \\
\hline \multirow{3}{*}{$\begin{array}{l}\text { Creative and } \\
\text { systematic } \\
\text { arrangement of } \\
\text { products }\end{array}$} & Pearson correlation & $0.598^{* *}$ & $0.526^{* *}$ & $0.670^{* *}$ & $0.473^{* *}$ & 1 & $0.504^{* *}$ \\
\hline & Sig. (2-tailed) & 0.000 & 0.000 & 0.000 & 0.000 & & 0.000 \\
\hline & $\mathrm{N}$ & 385 & 385 & 385 & 385 & 385 & 385 \\
\hline \multirow{3}{*}{$\begin{array}{l}\text { Comfortable and } \\
\text { well-maintained trial } \\
\text { rooms }\end{array}$} & Pearson correlation & $0.525^{* *}$ & $0.576^{* *}$ & $0.574^{* *}$ & $0.656^{* *}$ & $0.504^{* *}$ & 1 \\
\hline & Sig. (2-tailed) & 0.000 & 0.000 & 0.000 & 0.000 & 0.000 & \\
\hline & N & 385 & 385 & 385 & 385 & 385 & 385 \\
\hline
\end{tabular}

Note: ${ }^{* *}$ correlation is significant at 0.01 level (2-tailed).

that not only should correlate with related variables, but it also should not correlate with dissimilar and unrelated ones (de Vet, Terwee, Mokkink, \& Knol, 2011; Streiner, Norman, \& Cairney, 2015). The study examines the concurrent validity of the respondents' impulse buying behavior with three sets of factors, i.e., store layout, ambiance factor, and employee interaction, with convergent and discriminant analysis.

Table 1 presents the convergent validity of the store layout comprising of six items. Convergent validity examines the strength of the variables.

From Table 1, it is observed that there exists a strong correlation between the variables of store layout, with $p$-value $0.000<0.005$ at $1 \%$ significance level.
Table 2 presents that the independent variables of store layout are significant at $0.000<0.005$. Hence, the discriminant dimensions are highly significant and show a strong relationship.

Table 3 interprets the convergent validity of store ambiance comprising of four items. The strength of the variables is measured through convergent validity.

Table 3 shows a strong correlation between store ambiance variables, with $p$-value $0.000<0.005$ at $1 \%$ significance level.

Table 4 shows that the independent variables of store ambiance are significant at $0.000<0.005$. Hence, the discriminant dimensions are highly significant and show a strong relationship.

Table 2. Discriminant validity of store layout

\begin{tabular}{|c|c|c|c|c|c|}
\hline Store Layout & Wilks' Lambda & $\mathbf{F}$ & df1 & df2 & Sig. \\
\hline Well-structured layout & 0.731 & 35.003 & 4 & 380 & 0.000 \\
\hline Pleasing store décor & 0.858 & 15.666 & 4 & 380 & 0.000 \\
\hline Attractive display & 0.710 & 38.830 & 4 & 380 & 0.000 \\
\hline Pay attention to the window display & 0.798 & 24.078 & 4 & 380 & 0.000 \\
\hline The creative and systematic arrangement of products & 0.780 & 26.799 & 4 & 380 & 0.000 \\
\hline Comfortable and well-maintained trial rooms & 0.739 & 33.633 & 4 & 380 & 0.000 \\
\hline
\end{tabular}


Table 3. Correlation between the variables of store ambiance

\begin{tabular}{|c|c|c|c|c|c|}
\hline \multirow{3}{*}{ Variables: Store Ambience } & & & The good scent & In-store lighting & Cleanliness \\
\hline & & stimulates to buy & in the store leads & is pleasing to the & influences to buy \\
\hline & & more & to a longer stay & eyes & more \\
\hline \multirow{3}{*}{$\begin{array}{l}\text { Pleasant music stimulates to } \\
\text { buy more }\end{array}$} & Pearson correlation & 1 & $0.432^{* *}$ & $0.740^{* *}$ & $0.493^{* *}$ \\
\hline & Sig. (2-tailed) & & 0.000 & 0.000 & 0.000 \\
\hline & N & 385 & 385 & 385 & 385 \\
\hline \multirow{3}{*}{$\begin{array}{l}\text { The good scent in the store } \\
\text { leads to a longer stay }\end{array}$} & Pearson correlation & $0.432^{* *}$ & 1 & $0.422^{* *}$ & $0.623^{* *}$ \\
\hline & Sig. (2-tailed) & 0.000 & & 0.000 & 0.000 \\
\hline & $\mathrm{N}$ & 385 & 385 & 385 & 385 \\
\hline \multirow{3}{*}{$\begin{array}{l}\text { In-store lighting is pleasing to } \\
\text { the eyes }\end{array}$} & Pearson correlation & $0.740^{* *}$ & $0.422^{* *}$ & 1 & $0.545^{* *}$ \\
\hline & Sig. (2-tailed) & 0.000 & 0.000 & & 0.000 \\
\hline & N & 385 & 385 & 385 & 385 \\
\hline \multirow{3}{*}{$\begin{array}{l}\text { Cleanliness influences to buy } \\
\text { more }\end{array}$} & Pearson correlation & $0.493^{* *}$ & $0.623^{* *}$ & $0.545^{* *}$ & 1 \\
\hline & Sig. (2-tailed) & 0.000 & 0.000 & 0.000 & \\
\hline & N & 385 & 385 & 385 & 385 \\
\hline
\end{tabular}

Note: ${ }^{*}$ correlation is significant at 0.01 level (2-tailed).

Table 4. Discriminant validity of store ambiance

\begin{tabular}{l|c|c|c|c|c}
\hline \multicolumn{1}{c}{ Store Ambience } & Wilks' Lambda & F & df1 & df2 & Sig. \\
\hline Pleasant music stimulates to buy more & 0.746 & 32.408 & 4 & 380 & 0.000 \\
The good scent in the store leads to a longer stay & 0.671 & 46.501 & 4 & 380 & 0.000 \\
In-store lighting is pleasing to the eyes & 0.709 & 38.941 & 4 & 380 & 0.000 \\
Cleanliness influences to buy more & 0.699 & 40.991 & 4 & 380 & 0.000 \\
\hline
\end{tabular}

Table 5. Correlation between the variables of employee interactions

\begin{tabular}{|c|c|c|c|c|c|}
\hline $\begin{array}{l}\text { Variables: Employee } \\
\text { Interactions }\end{array}$ & & $\begin{array}{c}\text { Sufficient } \\
\text { employees to } \\
\text { serve customers }\end{array}$ & $\begin{array}{c}\text { Knowledgeable } \\
\text { employees to } \\
\text { guide the customer }\end{array}$ & $\begin{array}{c}\text { Friendly } \\
\text { and helpful } \\
\text { employees }\end{array}$ & $\begin{array}{l}\text { Gracious } \\
\text { greeting by the } \\
\text { employees }\end{array}$ \\
\hline \multirow{3}{*}{$\begin{array}{l}\text { Sufficient employees to serve } \\
\text { customers }\end{array}$} & Pearson correlation & 1 & $0.468^{* *}$ & $0.690^{* *}$ & $0.428^{* *}$ \\
\hline & Sig. (2-tailed) & & 0.000 & 0.000 & 0.000 \\
\hline & $\mathrm{N}$ & 385 & 385 & 385 & 385 \\
\hline \multirow{3}{*}{$\begin{array}{l}\text { Knowledgeable employees to } \\
\text { guide the customer }\end{array}$} & Pearson correlation & $0.468^{* *}$ & 1 & $0.426^{* *}$ & $0.761^{* *}$ \\
\hline & Sig. $(2$-tailed) & 0.000 & & 0.000 & 0.000 \\
\hline & N & 385 & 385 & 385 & 385 \\
\hline \multirow{3}{*}{$\begin{array}{l}\text { Friendly and helpful } \\
\text { employees }\end{array}$} & Pearson correlation & $0.690^{* *}$ & $0.426^{* *}$ & 1 & $0.451^{* *}$ \\
\hline & Sig. (2-tailed) & 0.000 & 0.000 & & 0.000 \\
\hline & N & 385 & 385 & 385 & 385 \\
\hline \multirow{3}{*}{$\begin{array}{l}\text { Gracious greeting by the } \\
\text { employees }\end{array}$} & Pearson correlation & $0.428^{* *}$ & $0.761^{* *}$ & $0.451^{* *}$ & 1 \\
\hline & Sig. $(2$-tailed) & 0.000 & 0.000 & 0.000 & \\
\hline & N & 385 & 385 & 385 & 385 \\
\hline
\end{tabular}

Note: ${ }^{* *}$ correlation is significant at 0.01 level (2-tailed).

Table 6. Discriminant validity for employee interaction

\begin{tabular}{l|c|c|c|c|c}
\hline \multicolumn{1}{c|}{ Employee Interaction } & Wilks' Lambda & F & df1 & df2 & Sig. \\
\hline Sufficient employees to serve customers & 0.584 & 67.752 & 4 & 380 & 0.000 \\
Knowledgeable employees to guide the customer & 0.853 & 16.431 & 4 & 380 & 0.000 \\
Friendly and helpful employees & 0.698 & 41.180 & 4 & 380 & 0.000 \\
Gracious greeting by the employees & 0.862 & 15.176 & 4 & 380 & 0.000 \\
\hline
\end{tabular}


Table 5 interprets the convergent validity of employee interaction comprising of four items. The strength of the variables is measured through convergent validity.

Table 5 shows a strong correlation between the variables of employee interaction, with $p$-value $0.000<0.005$ at $1 \%$ significance level.

Table 6 shows that the independent variables of employee interaction are significant at $0.000<$ 0.005 . Hence, the discriminant dimensions are highly significant and show a strong relationship.

\section{RESULTS AND DISCUSSION}

The following section provides an analysis of the data obtained from the survey.

Table 7. Demographic profile

\begin{tabular}{|c|c|c|c|}
\hline Demographics & Classification & Count & Percentage \\
\hline \multirow{5}{*}{ Age } & $\begin{array}{l}\text { Below } 25 \\
\text { years }\end{array}$ & 140 & $36.4 \%$ \\
\hline & $25-35$ years & 112 & $29.1 \%$ \\
\hline & $36-45$ years & 73 & $19.0 \%$ \\
\hline & Above 46 & 60 & $15.6 \%$ \\
\hline & Total & 385 & $100.0 \%$ \\
\hline \multirow{4}{*}{ Occupation } & $\begin{array}{l}\text { Working } \\
\text { woman }\end{array}$ & 149 & $38.7 \%$ \\
\hline & Student & 142 & $36.9 \%$ \\
\hline & Homemaker & 94 & $24.4 \%$ \\
\hline & Total & 385 & $100.0 \%$ \\
\hline \multirow{5}{*}{$\begin{array}{l}\text { Frequency of visit to } \\
\text { the store }\end{array}$} & Once a month & 78 & $20.3 \%$ \\
\hline & Twice a month & 80 & $20.8 \%$ \\
\hline & $\begin{array}{l}\text { More than } \\
\text { twice a month }\end{array}$ & 92 & $23.9 \%$ \\
\hline & Occasionally & 135 & $35.1 \%$ \\
\hline & Total & 385 & $100.0 \%$ \\
\hline \multirow{4}{*}{$\begin{array}{l}\text { Revisit the store in } \\
\text { future }\end{array}$} & Yes & 314 & $81.6 \%$ \\
\hline & No & 14 & $3.6 \%$ \\
\hline & Maybe & 57 & $14.8 \%$ \\
\hline & Total & 385 & $100.0 \%$ \\
\hline
\end{tabular}

Table 7 shows that the sample consists of $36.4 \%$ of the respondents belonging to the age group of below 25 years, $29.1 \%$ of the respondents from the category $25-35$ years, $19 \%$ of the respondents belong to $36-45$ years, and $15.6 \%$ of the respondents are above 46 years. The majority of respondents are working women (38.7\%), 36.9\% are students, and $24.4 \%$ are homemakers. $35.1 \%$ of the respondents occasionally visit the store, $23.9 \%$ of the respondents visit the store more than twice a month, $20.8 \%$ visit twice a month, and $20.3 \%$ of the respondents visit once a month. $81.6 \%$ of the respondents revisit the store in future, $14.8 \%$ of the respondents may revisit the store, and only $3.6 \%$ of the respondents will not revisit the store in future.

\subsection{Impact of various factors on impulse buying behavior among female customers}

The effect of various factors on impulse buying behavior among the respondents is measured through 14 statements using a five-point Likert scale.

Table 8. Reliability statistics

\begin{tabular}{c|c|c}
\hline $\begin{array}{c}\text { Cronbach's } \\
\text { Alpha }\end{array}$ & $\begin{array}{c}\text { Cronbach's Alpha based on } \\
\text { standardized items }\end{array}$ & $\begin{array}{c}\text { No. of } \\
\text { items }\end{array}$ \\
\hline 0.943 & 0.943 & 14 \\
\hline
\end{tabular}

Table 8 shows the calculated Cronbach's Alpha of 0.943 , which indicates a very high level of internal consistency for 14 items defined, which shows that the scale used to measure factors on impulse buying behavior is highly reliable.

\subsection{Regression analysis to find the impact of store layout on impulse buying behavior}

Pradhan (2016, p. 227) has measured respondent's impulsiveness by considering two variables viz. spending 'more money than intended' and 'buy things spontaneously'. Accordingly, this study has performed multiple regression analysis by considering store layout as the independent variable and the impulse buying behavior "End up spending more money than planned", "Experienced sudden urges to buy unplanned apparels" as the dependent variables. Thus, further, there is hypothesized the store layout with six independent variables with the impulse buying behavior among female customers in apparel stores:

H1: The freeflow store layout encourages impulse buying behavior among female customers in apparel stores. 
Table 9. Regression analysis of the impact of store layout on impulse buying behavior

\begin{tabular}{|c|c|c|c|c|c|c|}
\hline \multirow[t]{2}{*}{ No. } & \multirow[t]{2}{*}{ Independent variables } & \multicolumn{2}{|c|}{$\begin{array}{l}\text { Unstandardized } \\
\text { coefficients }\end{array}$} & \multirow{2}{*}{\begin{tabular}{|c|}
$\begin{array}{c}\text { Standardized } \\
\text { coefficients }\end{array}$ \\
Beta
\end{tabular}} & \multirow[t]{2}{*}{$\mathbf{t}$} & \multirow[t]{2}{*}{ Sig. } \\
\hline & & B & Std. error & & & \\
\hline \multicolumn{2}{|r|}{ (Constant) } & 0.839 & 0.226 & & 3.713 & 0.000 \\
\hline 1 & Well-structured layout & -0.116 & 0.071 & -0.090 & -1.634 & 0.103 \\
\hline 2 & Pleasing store decor & 0.317 & 0.065 & 0.306 & 4.846 & $0.000^{* *}$ \\
\hline 3 & Attractive display & 0.149 & 0.067 & 0.136 & 2.230 & $0.026^{*}$ \\
\hline 4 & Pay attention to the window display & 0.051 & 0.069 & 0.050 & 0.747 & 0.456 \\
\hline 5 & $\begin{array}{l}\text { The creative and systematic arrangement of } \\
\text { products }\end{array}$ & 0.161 & 0.063 & 0.147 & 2.549 & $0.011^{*}$ \\
\hline 6 & Comfortable and well-maintained trial rooms & 0.227 & 0.057 & 0.223 & 3.958 & $0.000 * *$ \\
\hline
\end{tabular}

Note: a. Dependent variable: end up spending more money than planned. Significant at *0.05, ** 0.01 levels.

Table 10. Summary of adjusted $R$-squared

\begin{tabular}{c|c|c|c}
\hline $\mathbf{R}$ & $R$-squared & Adjusted $R$-squared & $p$-value \\
\hline 0.647 & 0.419 & 0.409 & $0.000^{* *}$ \\
\hline
\end{tabular}

Table 9 provides the standardized beta coefficients and $p$-value for the factors causing impulse buying behavior. The result shows that four factors were statistically significant among six factors, with a $p$-value less than 0.05 . They are (1) "pleasing store decor" $(\beta=0.306, p=0.000)$, (2) "attractive display" $(\beta=0.136, p=0.026)$, (3) "creative and systematic arrangement of products" ( $\beta=0.147, p=0.011)$, and (4) "comfortable and well maintained trial rooms" $(\beta=0.223$, $p=0.000)$. Other factors have a low impact on impulse buying behavior. However, they are not statistically significant.
Table 10 gives the adjusted $R$-squared value for impulse buying behavior. The overall impact of these factors on the level of impulse buying was $40.9 \%$.

Table 11 provides the standardized beta coefficients and p-value for the factors causing impulse buying behavior. The result shows that five factors were statistically significant among six factors, with a $p$-value less than 0.05 . They are (1) "well-structured layout" $(\beta=0.247, p=0.000)$, (2) "pleasing store decor" $(\beta=0.132, p=0.046)$, (3) "attractive display" ( $\beta=0.129, p=0.045)$, (4) "creative and systematic arrangement of products"

Table 11. Regression analysis of the impact of store layout on impulse buying behavior

\begin{tabular}{|c|c|c|c|c|c|c|}
\hline \multirow[t]{2}{*}{ No. } & \multirow[t]{2}{*}{ Independent variables } & \multicolumn{2}{|c|}{$\begin{array}{l}\text { Unstandardized } \\
\text { coefficients }\end{array}$} & \multirow{2}{*}{$\begin{array}{c}\begin{array}{c}\text { Standardized } \\
\text { coefficients }\end{array} \\
\text { Beta } \\
\end{array}$} & \multirow[t]{2}{*}{$\mathbf{t}$} & \multirow[t]{2}{*}{ Sig. } \\
\hline & & B & Std. error & & & \\
\hline \multicolumn{2}{|r|}{ (Constant) } & 1.487 & 0.187 & & 7.937 & 0.000 \\
\hline 1 & Well-structured layout & 0.25 & 0.059 & 0.247 & 4.248 & $0.000 * *$ \\
\hline 2 & Pleasing store decor & -0.108 & 0.054 & 0.132 & 2 & $0.046^{*}$ \\
\hline 3 & Attractive display & 0.111 & 0.055 & 0.129 & 2.015 & $0.045^{*}$ \\
\hline 4 & Pay attention to the window display & 0.07 & 0.057 & 0.087 & 1.235 & 0.218 \\
\hline 5 & The creative and systematic arrangement of products & 0.123 & 0.052 & 0.142 & 2.352 & $0.019 *$ \\
\hline 6 & Comfortable and well-maintained trial rooms & 0.187 & 0.048 & 0.232 & 3.922 & $0.000 * *$ \\
\hline
\end{tabular}

Note: a. Dependent variable: experienced sudden urges to buy unplanned apparel. Significant at * $0.05, * * 0.01$ levels.

Table 12. Summary of adjusted $R$-squared

\begin{tabular}{c|c|c|c}
\hline $\mathbf{R}$ & $\boldsymbol{R}$-squared & Adjusted $\boldsymbol{R}$-squared & $\boldsymbol{p}$-value \\
\hline 0.600 & 0.361 & 0.350 & $0.000^{* *}$ \\
\hline
\end{tabular}


( $\beta=0.142, p=0.019)$, and (5) "comfortable and well maintained trial rooms" $(\beta=0.232, p=0.000)$, while "pay attention to the window display" has a low impact on impulse buying behavior. However, it is statistically not significant.

Table 12 gives the adjusted $R$-squared value for impulse buying behavior. The overall impact of these factors on the level of impulse buying was $35.0 \%$.

The results of Table 10 and 12 show a positive influence of store layout on impulse buying behavior. So, hypothesis $H 1$ is accepted.

\subsection{Regression analysis to find the impact of ambient factors on impulse buying behavior}

Multiple regression analysis was performed by considering five factors about ambient factors as independent variables and impulse buying behavior "end up spending more money than planned" as the dependent variable. Therefore, the hypothesis is framed to examine how store ambiance influences impulse buying among female customers:

H2: Attractive store ambiance leads to impulse buying behavior among female customers in apparel stores.

Table 13 provides the standardized beta coefficients and $p$-value for the ambient factors causing impulse buying behavior. The result reveals that among four factors, all four factors were statistically significant, with a $p$-value less than 0.05 . They are (1) "pleasant music stimulates to buy more" ( $\beta=0.304, p=0.000)$, (2) "good scent in the store leads to longer stay" ( $\beta=0.128, p=0.007)$, (3) "in-store lighting is pleasing to the eyes" $(\beta=0.301$, $p=0.000$ ), and (4) "cleanliness influences to buy more" $(\beta=0.109, p=0.033)$.

Table 14 gives the adjusted $R$-squared value for impulse buying behavior. The overall impact of these factors on the level of impulse buying was $49.4 \%$.

Table 15 provides the standardized beta coefficients and $p$-value for the ambient factors causing impulse buying behavior. The result reveals that among four factors, three factors were statistically significant, with a $p$-value less than 0.05 . They are (1) "the good scent in the store leads to longer stay" ( $\beta=0.317, p=0.000)$, (2) "in-store lighting is pleasing to the eyes" $(\beta=0.213, p=0.001)$, and (3) "cleanliness influences to buy more" $(\beta=0.185$, $p=0.001)$. Another factor has a low impact on impulse buying behavior. However, it is not statistically significant.

Table 16 gives the adjusted $R$-squared value for impulse buying behavior. The overall impact of these factors on the level of impulse buying was $41.2 \%$.

The results of Tables 14 and 16 show a positive influence of store ambiance on impulse buying behavior. So, hypothesis $H 2$ is accepted.

Table 13. Regression analysis of the impact of store ambiance on impulse buying behavior

\begin{tabular}{|c|c|c|c|c|c|c|}
\hline \multirow[t]{2}{*}{ No. } & \multirow[t]{2}{*}{ Independent variables } & \multicolumn{2}{|c|}{$\begin{array}{l}\text { Unstandardized } \\
\text { coefficients }\end{array}$} & \multirow{2}{*}{$\begin{array}{c}\begin{array}{c}\text { Standardized } \\
\text { coefficients }\end{array} \\
\text { Beta }\end{array}$} & \multirow[t]{2}{*}{$\mathbf{t}$} & \multirow[t]{2}{*}{ Sig. } \\
\hline & & B & Std. error & & & \\
\hline & (Constant) & 0.662 & 0.191 & & 3.468 & 0.001 \\
\hline 1 & Pleasant music stimulates to buy more & 0.295 & 0.053 & 0.304 & 5.514 & $0.000 * *$ \\
\hline 2 & $\begin{array}{l}\text { The good scent in the store leads to a longer } \\
\text { stay }\end{array}$ & 0.138 & 0.051 & 0.128 & 2.714 & $0.007^{*}$ \\
\hline 3 & In-store lighting is pleasing to the eyes & 0.294 & 0.055 & 0.301 & 5.306 & $0.000 * *$ \\
\hline 4 & Cleanliness influences to buy more & 0.116 & 0.054 & 0.109 & 2.141 & $0.033^{*}$ \\
\hline
\end{tabular}

Note: a. Dependent variable: end up spending more money than planned. Significant at $* 0.05, * * 0.01$ levels.

Table 14. Summary of adjusted $R$-squared

\begin{tabular}{c|c|c|c}
\hline $\mathbf{R}$ & $\boldsymbol{R}$-squared & Adjusted $\boldsymbol{R}$-squared & $\boldsymbol{p}$-value \\
\hline 0.707 & 0.499 & 0.494 & $0.000^{* *}$ \\
\hline
\end{tabular}


Table 15. Regression analysis of the impact of store ambiance on impulse buying behavior

\begin{tabular}{|c|c|c|c|c|c|c|}
\hline \multirow[t]{2}{*}{ No. } & \multirow[t]{2}{*}{ Independent variables } & \multicolumn{2}{|c|}{$\begin{array}{c}\text { Unstandardized } \\
\text { coefficients }\end{array}$} & \multirow{2}{*}{$\begin{array}{c}\begin{array}{c}\text { Standardized } \\
\text { coefficients }\end{array} \\
\text { Beta }\end{array}$} & \multirow[t]{2}{*}{$\mathbf{t}$} & \multirow[t]{2}{*}{ Sig. } \\
\hline & & B & Std. error & & & \\
\hline \multicolumn{2}{|r|}{ (Constant) } & 1.389 & 0.163 & & 8.537 & 0.000 \\
\hline 1 & Pleasant music stimulates to buy more & 0.060 & 0.046 & 0.078 & 1.310 & 0.191 \\
\hline 2 & The good scent in the store leads to a longer stay & 0.269 & 0.043 & 0.317 & 6.221 & $0.000 * *$ \\
\hline 3 & In-store lighting is pleasing to the eyes & 0.164 & 0.047 & 0.213 & 3.475 & $0.001^{*}$ \\
\hline 4 & Cleanliness influences to buy more & 0.156 & 0.046 & 0.185 & 3.382 & $0.001^{*}$ \\
\hline
\end{tabular}

Note: a. Dependent variable: experienced sudden urges to buy unplanned apparel. Significant at *0.05, ** 0.01 levels.

Table 16. Summary of adjusted $R$-squared

\begin{tabular}{c|c:c|c}
\hline $\mathbf{R}$ & $\boldsymbol{R}$-squared & Adjusted $\boldsymbol{R}$-squared & $\boldsymbol{p}$-value \\
\hline 0.647 & 0.418 & 0.412 & $0.000^{* *}$ \\
\hline
\end{tabular}

\subsection{Regression analysis to find the impact of store employee interaction on impulse buying behavior}

Multiple regression analysis was performed by considering five factors about store employee interaction as independent variables and impulse buying behavior "end up spending more money than planned" as the dependent variable. Hence, the hypothesis is formulated to test the effect of employee interaction on the impulse buying behavior of female customers:

H3: Store employees' interaction with female customers positively influences their impulse buying behavior.
Table 17 provides the standardized beta coefficients and $p$-value for the factors causing impulse buying behavior. The result shows that among four factors, two factors were statistically significant, with a $p$-value less than 0.05 . They are (1) "knowledgeable employees to guide customer" $(\beta$ $=0.492, p=0.000)$ and (2) "gracious greeting by the employees" $(\beta=0.259, p=0.000)$. Other factors have a low impact on impulse buying behavior. However, they are not statistically significant.

Table 18 gives the adjusted $R$-squared value for impulse buying behavior. The overall impact of these factors on the level of impulse buying was 54.3\%.

Table 19 provides the standardized beta coefficients and $p$-value for the factors causing impulse buying behavior. The result shows that one factor

Table 17. Regression analysis of the impact of store employees' interaction on customers' impulse buying behavior

\begin{tabular}{|c|c|c|c|c|c|c|}
\hline \multirow[t]{2}{*}{ No. } & \multirow[t]{2}{*}{ Independent variables } & \multicolumn{2}{|c|}{$\begin{array}{c}\text { Unstandardized } \\
\text { coefficients }\end{array}$} & \multirow{2}{*}{$\begin{array}{c}\begin{array}{c}\text { Standardized } \\
\text { coefficients }\end{array} \\
\text { Beta }\end{array}$} & \multirow[t]{2}{*}{$\mathbf{t}$} & \multirow[t]{2}{*}{ Sig. } \\
\hline & & B & Std. error & & & \\
\hline \multicolumn{2}{|r|}{ (Constant) } & 0.612 & 0.204 & & 2.995 & 0.003 \\
\hline 1 & Sufficient employees to serve customers & 0.001 & 0.063 & 0.001 & 0.010 & 0.992 \\
\hline 2 & Knowledgeable employees to guide the customer & 0.496 & 0.055 & 0.492 & 8.974 & $0.000 * *$ \\
\hline 3 & Friendly and helpful employees & 0.072 & 0.056 & 0.063 & 1.290 & 0.198 \\
\hline 4 & Gracious greeting by the employees & 0.272 & 0.057 & 0.259 & 4.750 & $0.000 * *$ \\
\hline
\end{tabular}

Note: a. Dependent variable: end up spending more money than planned. Significant at $* 0.05, * * 0.01$ levels

Table 18. Summary of adjusted $R$-squared

\begin{tabular}{c|c:c|c}
\hline $\mathbf{R}$ & $\boldsymbol{R}$-squared & Adjusted $\boldsymbol{R}$-squared & $\boldsymbol{p}$-value \\
\hline 0.740 & 0.548 & 0.543 & $0.000^{* *}$ \\
\hline
\end{tabular}


Table 19. Regression analysis of the impact of store employees' interaction on customers' impulse buying behavior

\begin{tabular}{|c|c|c|c|c|c|c|}
\hline \multirow[t]{2}{*}{ No. } & \multirow[t]{2}{*}{ Independent variables } & \multicolumn{2}{|c|}{$\begin{array}{c}\text { Unstandardized } \\
\text { coefficients }\end{array}$} & \multirow{2}{*}{$\begin{array}{c}\begin{array}{c}\text { Standardized } \\
\text { coefficients }\end{array} \\
\text { Beta }\end{array}$} & \multirow[t]{2}{*}{$\mathbf{t}$} & \multirow[t]{2}{*}{ Sig. } \\
\hline & & B & Std. error & & & \\
\hline & (Constant) & 1.277 & 0.189 & & 6.771 & 0.000 \\
\hline 1 & Sufficient employees to serve customers & 0.507 & 0.058 & 0.503 & 8.715 & $0.000 * *$ \\
\hline 2 & Knowledgeable employees to guide the customer & 0.038 & 0.051 & 0.048 & 0.745 & 0.457 \\
\hline 3 & Friendly and helpful employees & 0.084 & 0.051 & .094 & 1.631 & 0.104 \\
\hline 4 & Gracious greeting by the employees & 0.036 & 0.053 & 0.044 & 0.684 & 0.494 \\
\hline
\end{tabular}

Note: a. Dependent variable: experienced sudden urges to buy unplanned apparel. Significant at *0.05, ** 0.01 levels.

Table 20. Summary of adjusted $R$-squared

\begin{tabular}{c|c|c|c}
\hline $\mathbf{R}$ & $\boldsymbol{R}$-squared & Adjusted $\boldsymbol{R}$-squared & $\boldsymbol{p}$-value \\
\hline 0.619 & 0.383 & 0.377 & $0.000^{* *}$ \\
\hline
\end{tabular}

is statistically significant among four factors, with a $p$-value less than 0.05 . That is "sufficient employees to serve customers" $(\beta=0.503, p=0.000)$. Other factors have a low impact on impulse buying behavior. However, they are not statistically significant.

Table 20 gives the adjusted $R$-squared for impulse buying behavior. The overall impact of these factors on the level of impulse buying was $37.7 \%$.

Tables 18 and 20 show a positive influence on store employees' interaction on customers' impulse buying behavior. So, hypothesis $H 3$ is accepted.

\section{DISCUSSION}

This study extends the understanding of impulse buying, specifically among female customers, in India's rapidly evolving apparel industry.The study found that female shoppers make impulse purchases predominantly during their visit to the stores. The sample had the highest share of working women (38.7\%), implying the increased purchasing power due to additional income. It also shows that the stores surveyed are innovative, visually appealing and stimulating the impulse buying intention. Among the three constructs considered for the study, 'store ambiance' emerged to be the leading factor influencing the impulse buying behavior. The impact of ambiance on impulse buying behavior was measured consistently above $40 \%$ for both the indicators of impulse buying, i.e., "end up spending more mon- ey than planned" and "experienced sudden urges to buy unplanned apparels". Pradhan (2016) claimed that "the impulsive buying behavior displayed by consumers in supermarkets may not be applicable in each and every environment" and, thus, store environment is a key determinant leading to impulse buying behavior in apparel stores.

The window displays in the stores surveyed are perceived as not eye-catching and, hence, shows no impact on impulse buying, while all other elements under the store layout have contributed to impulse buying with store decor as the leading factor followed by the layout.

The result also shows that among all the underlying factors, 'sufficient employees in the store' had the highest effect on the impulse buying intention, followed by knowledgeable employee guidance. This shows that the number of sales staff and their retail skills are critical aspects to impulse buying decisions made by female shoppers in apparel stores. Moreover, Ansari (2013) opined that "the personal attributes and character formulation of the staff member suffer from rigidity" in Indian apparel stores. This is reflected in the study with employees' friendly and helping nature, having no impact on impulse buying.

\section{MANAGERIAL IMPLICATIONS}

The study offers significant insights into the impact of atmospheric and social stimuli on impulse 
buying behavior among female shoppers in the Indian apparel retail context. The outcomes of this research are consistent with the previous researches (Mohan et al., 2013; Atulkar \& Kesari, 2018) on impulse buying in organized retail outlets in India.

Shoppers who perceive the store atmosphere more positively are expected to spend more time in the store and make impulse purchases. The window display followed in the stores surveyed was not effective in driving impulse purchases. This could be due to customers' familiarity with similar display patterns across the apparel stores or female shoppers who are high sensation seekers when it comes to fashion products. Hence, store managers should invest in window displays that stand out from the crowd, make a great first impression, and drive foot traffic.

The survey also indicates that female shoppers are significantly influenced by the number of store associates and personal interaction. This implies that women are more vulnerable to im- pulse buying during apparel shopping. Findings of Tulungen (2013) support this argument. However, the Indian retail sector is facing one of the biggest challenges in the form of attrition rate, which is around 40-45\% (Maheshwari \& Verma, 2016). Thus, store managers should focus on retaining the best talents for building customer satisfaction and store loyalty.

The store scent under the ambiance construct turned out to be a key determinant of the impulse purchase. This indicates that the right choice of scent in the store can enhance the perception of merchandise quality and, thus, could influence the shoppers to prolong their stay in the store leading to impulse purchase. The store managers need to reflect upon the fragrances the customers prefer at large since the above stores offer merchandise to all ages and across genders. Store managers could preferably use traditional aromas near the entrance and common area and use combinations to evoke the brand identity.

\section{CONCLUSION}

The productiveness of in-store stimuli in generating additional sales is of significance to the retailers since it helps to differentiate their store from the competitors' offerings (Abratt \& Goodey, 1990). The study strengthens the literature by analyzing the impulse buying behavior among Indian shoppers from Southern India. The study presents important findings concerning the role of three constructs, such as store layout, store ambiance, and store employees on the customers' buying intentions. The result of the study indicates that all three constructs significantly positively influence impulse buying behavior. Further, twelve out of fourteen factors examined in the study are found to influence impulse buying behavior. In contrast, factors such as paying attention to the window display, friendly and helpful employees did not show any association with a sudden urge to buy or spend more money than planned and, thus, impulse buying behavior. During the survey, the staffing in the stores was limited, which could be the reason for the lack of association with impulse purchases.

The modern Indian women are well educated, enlightened and tech-savvy. They are keen on shopping especially, the apparels and often make emotional spending through impulse purchases. The trend is encouraging in the years ahead, considering their increased spending on apparels. The study concludes that female shoppers are impulsive towards apparel products and their impulsivity can be elevated by felicitous employee intervention and judicious spending on the store interior designs, especially the choice of ambient scents which can induce a feeling of inquisitiveness.

\section{Limitations and future scope}

While the study has important contributions, it also has some shortcomings. The study concluded the impulse buying behavior of respondents in the store based on two important indicators of impulse buying, i.e., the urge to buy spontaneously and spend more money than planned. Furthermore, the study 
ignored the influence of in-store promotion, point of purchase (POP) deals, impulse buying tendency of shoppers, and peer influence on impulse purchase behavior.

It is important to realize the traffic flow and navigation patterns of both men and women in apparel stores to optimize their shopping experience and strategize store layout. Also, comfortable trial rooms are found to be crucial to impulse sales. Aspects such as trial room space, ventilation, waiting area for shoppers accompanying the buyer are important areas to be considered. Future studies on store layout should investigate the relevance of trial rooms in driving shopper satisfaction and increased sales in the context of apparel retailing.

\section{AUTHOR CONTRIBUTIONS}

Conceptualization: Iqbal Thonse Hawaldar, Prakash Pinto.

Data curation: Vinish P, Slima Pinto.

Formal analysis: Vinish P, Iqbal Thonse Hawaldar, Slima Pinto.

Investigation: Prakash Pinto, Slima Pinto.

Methodology: Vinish P, Iqbal Thonse Hawaldar.

Project administration: Prakash Pinto.

Software: Vinish P, Slima Pinto.

Validation: Iqbal Thonse Hawaldar.

Writing - original draft: Vinish P.

Writing - review \& editing: Vinish P, Prakash Pinto, Slima Pinto, Iqbal Thonse Hawaldar.

\section{REFERENCES}

1. Abratt, R., \& Goodey, S. D. (1990). Unplanned Buying and In-Store Stimuli in Supermarkets. Managerial and Decision Economics, 11(2), 111-121. https:// doi.org/10.1002/mde.4090110204

2. Adler, J., Csikszentmihalyi, M., \& Rochberg-Halton, E. (1983). The Meaning of Things: Domestic Symbols and the Self. Contemporary Sociology, 12, 452-453. https://doi. org/10.2307/2067526

3. Amos, C., Holmes, G. R., \& Keneson, W. C. (2014). A metaanalysis of consumer impulse buying. Journal of Retailing and Consumer Services, 21(2), 86-97. https://doi.org/10.1016/j.jretconser.2013.11.004

4. Ansari, S. (2013). Apparel Retailing: Challenges and Prospects in India (University of Lucknow). Retrieved from http:// shodhganga.inflibnet.ac.in/bitstream/10603/42500/2/saukat ansari thesis.pdf

5. Areni, C. S., \& Kim, D. (1994). The influence of in-store lighting on consumers' examination of merchandise in a wine store. International Journal of Research in Marketing, 11(2), 117-125. https://doi.org/10.1016/01678116(94)90023-X

6. Atulkar, S., \& Kesari, B. (2017). Impulse Buying: A Consumer Trait Prospective in Context of Central India. Global Business Review, 19(2), 477-493. https://doi. org/10.1177/0972150917713546

7. Atulkar, S., \& Kesari, B. (2018). Role of consumer traits and situational factors on impulse buying: does gender matter? International Journal of Retail and Distribution Management, 46(4), 386-405. https://doi.org/10.1108/ IJRDM-12-2016-0239

8. Badgaiyan, A. J., \& Verma, A. (2014). Intrinsic factors affecting impulsive buying behaviourevidence from India. Journal of Retailing and Consumer Services, 21(4), 537-549. https:// doi.org/10.1016/j.jretconser.2014.04.003
9. Badgaiyan, A. J., \& Verma, A. (2015). Does urge to buy impulsively differ from impulsive buying behaviour? Assessing the impact of situational factors. Journal of Retailing and Consumer Services, 22, 145-157. https:// doi.org/10.1016/j.jretconser.2014.10.002

10. Baker, J., Levy, M., \& Grewal, D. (1992). An experimental approach to making retail store environment decisions. Journal of Retailing, 68, 445-460. Retrieved from https:// www.researchgate.net/publication/303166632_An_experimental_approach_to_making_retail_ store_environment_decisions

11. Beatty, S. E., \& Ferrell, E. M. (1998). Impulse buying: Modeling its precursors. Journal of Retailing, 74(2), 169-191. https://doi.org/10.1016/S00224359(99)80092-X

12. Bellenger, Danny N., Robertson, Dan H., \& Hirschman, E. C. (1978). Impulse Buying Varies by Product. Journal of Advertising Research, 18(6), 15. Retrieved 
from https://search.proquest.com/ docview/205121977/905D091AE 4C54D4APQ/1 ?accountid=193930

13. Bellizzi, J. A., Crowley, A. E., \& Hasty, R. W. (1983). The effects of color in-store design. Journal of Retail, 59(1), 21-45. Retrieved from https://psycnet.apa.org/ record/1984-10983-001

14. Bellizzi, J. A., \& Hite, R. E. (1992). Environmental Color, Consumer Feelings, and Purchase Likelihood. Psychology \& Marketing, 9(5), 347-363. https://doi.org/10.1002/ mar.4220090502

15. Bitner, M. (1990). Evaluating Service Encounters: The Effects of Physical Surroundings and Employee Responses. Journal of Marketing, 54(2), 69-82. Retrieved from https://www.jstor.org/ stable/1251871?seq $=1$

16. Bitner, M. J. (1992). Servicescapes: the impact of Physical Surroundings on Customers and Employees. Journal of Marketing, 56, 57-71. https://doi.org/10.1177 $\% 2 F 002224299205600205$

17. Bloch, P. H. (1986). The Product Enthusiast: Implications for Marketing Strategy. Journal of Consumer Marketing, 3(3), 51-62. https://doi.org/10.1108/eb008170

18. Brengman, M. (2002). The impact of colour in the store environment: an environmental psychology approach.

19. Cakanlar, A., \& Nguyen, T. (2019). The influence of culture on impulse buying. Journal of Consumer Marketing, 36(1), 12-23. https://doi.org/10.1108/JCM-032017-2139

20. Chang, H. J., Yan, R. N., \& Eckman, M. (2014). Moderating effects of situational characteristics on impulse buying. International Journal of Retail and Distribution Management, 42(4), 298-

314. https://doi.org/10.1108/ IJRDM-04-2013-0074

21. Cottet, P., Lichtle, M.-C., \& Plichon, V. (2010). The Influence of Ambient Factors in Services: The Compared Effects of Perceived Colors and Store Layout. The 11th International Research Seminar in Service Management, (June),
1-24. Retrieved from http:// www.lalondeconference.com SM/2010_lalonde_seminar/ papers/p08-112-cottet-plichonlichtlerev25032010.pdf

22. Crawford, G., \& Melewar, T. C. (2003). The importance of impulse purchasing behaviour in the international airport environment. Journal of Consumer Behaviour, 3(1), 85-98. https://doi. org/10.1002/cb.124

23. de Vet, H. C. W., Terwee, C. B., Mokkink, L. B., \& Knol, D. L. (2011). Measurement in Medicine: A Practical Guide. https://doi. org/10.1017/CBO9780511996214

24. Ding, C. G., \& Lin, C. H. (2012). How does background music tempo work for online shopping? Electronic Commerce Research and Applications, 11(3), 299307. https://doi.org/10.1016/j. elerap.2011.10.002

25. Dittmar, H., Beattie, J., \& Friese, S. (1995). Gender identity and material symbols: Objects and decision considerations in impulse purchases. Journal of Economic Psychology, 16(3), 491-511. https://doi.org/10.1016/01674870(95)00023-H

26. Donovan, R. J., Rossiter, J. R., Marcoolyn, G., \& Nesdale, A. (1994). Store Atmosphere and Purchase Behavior. Journal of Retailing, 70(3), 283-294. https://doi.org/10.1016/00224359(94)90037-X

27. Dube, L., \& Morin, S. (2001). Background music pleasure and store evaluation: Intensity effects and psychological mechanisms. Journal of Business Research, 54(2), 107-113. https://doi.org/10.1016/ S0148-2963(99)00092-2

28. Floh, A., \& Madlberger, M. (2013). The role of atmospheric cues in online impulse-buying behavior. Electronic Commerce Research and Applications, 12(6), 425439. https://doi.org/10.1016/j. elerap.2013.06.001

29. Gerard, R. M. (1958). Differential effects of colored lights on psychophysiological functions. University of California, Los Angeles.
30. Global Data Lab. (2019). Subnational Human Development Index (4.0). Retrieved from Institute for Management Research, Radboud University website: https://globaldatalab. org/shdi/shdi/IND/?interpolat ion $=0$ \&extrapolation $=0$ \&neare st_real $=0 \% 0$ Ahttps://globaldatalab.org/shdi/shdi/

31. Goldsmith, R. E., \& Emmert, J. (1991). Measuring product category involvement: A multitrait-multimethod study. Journal of Business Research, 23(4), 363-371. https://doi. org/10.1016/0148-2963(91)90021$\mathrm{O}$

32. Gopal, V. (2010). Impact of Instore Music on Shopper Behavior. Journal of Business and Retail Management Research, 5(1), 65-75. Retrieved from https://jbrmr.com/ cdn/article_file/i-4_c-22.pdf

33. Hawaldar, I. T., Ullal, M. S., Birau, F. R., \& Spulbar, C. M. (2019). Trapping Fake Discounts as Drivers of Real Revenues and Their Impact on Consumer's Behavior in India: A Case Study. Sustainability, 11(17), 4637. https://doi.org/10.3390/ su11174637

34. Herabadi, A. G., Verplanken, B. \& Van Knippenberg, A. (2009). Consumption experience of impulse buying in Indonesia: Emotional arousal and hedonistic considerations. Asian Journal of Social Psychology, 12(1), 20-31. https://doi.org/10.1111/j.1467839X.2008.01266.x

35. Hoch, S. J., \& Loewenstein, G. F. (1991). Time-Inconsistent Preferences and Consumer SelfControl. Journal of Consumer Research, 17(4), 492. Retrieved from https://search.proquest.com/ docview/215039169/DBC157B3C $40741 \mathrm{C} 2 \mathrm{PQ} / 1$ ? accountid $=193930$

36. Husnain, M., Rehman, B., Syed, F., \& Akhtar, M. W. (2019). Personal and In-store Factors Influencing Impulse Buying Behavior among Generation Y Consumers of Small Cities. Business Perspectives and Research, 7(1), 92-107. https://doi. org/10.1177/2278533718800625

37. Hwang, H., Choi, B., \& Lee, M.-J. (2005). A model for shelf 
space allocation and inventory control considering location and inventory level effects on demand. International Journal of Production Economics, 97(2), 185-195. https:// doi.org/10.1016/j.ijpe.2004.07.003

38. IBEF. (2018). Karnataka: The Silicon Valley of India. Retrieved from https://www.ibef.org/download/Karnataka-April-20181.pdf

39. IBEF. (2019). Retail. Retrieved from India Brand Equity Foundation website: https://www. ibef.org/download/retail-jan-2019. pdf

40. Iberahim, H., Zureena, Z. N. A., Adila, R. A. S. R. N., \& Quraisyiah, R. S. (2018). Determinants of Customer Impulse Buying Behavior at Product Specialist Fashion Retail Stores. Journal of Economic \& Management Perspectives, 12(1), 538-544. Retrieved from https://search. proquest.com/openview/5619bc9d 7f4322ef073a05454254115b/1?pqorigsite $=$ gscholar $\& \mathrm{cbl}=51667$

41. Ju, J., \& Ahn, J. H. (2016). The effect of social and ambient factors on impulse purchasing behavior in social commerce. Journal of Organizational Computing and Electronic Commerce, 26(4), 285 306. https://doi.org/10.1080/10919 392.2016.1228353

42. Kacen, J. J., Hess, J. D., \& Walker, D. (2012). Spontaneous selection: The influence of product and retailing factors on consumer impulse purchases. Journal of Retailing and Consumer Services, 19(6), 578-588. https:// doi.org/10.1016/j.jretconser.2012.07.003

43. Kaiser, S. B. (1997). The social psychology of clothing (2nd ed.). New York: Fairchild Publications.

44. Kim, H. (2005). Consumer profiles of apparel product involvement and values. Journal of Fashion Marketing and Management, 9(2), 207-220. https://doi. org/10.1108/13612020510599358

45. Kotler, P. (1974). Atmospherics as a marketing tool. Journal of Retailing, 49, 48-64.

46. Lai, C., \& Chang, K.-M. (2015). Effect of Background Music and Visual Display on Shopping Website Browsing and Purchasing Process. Proceedings of the Second European Academic Research Conference on Global Business, Economics, Finance and Banking (EAR15Swiss Conference), 3-5. Retrieved from http://globalbizresearch.org/Swiss_Conference/pdf/ Z560.pdf

47. Levav, J., \& Zhu, R. (2009). Seeking Freedom through Variety. Journal of Consumer Research, 36(4), 600-610. https://doi. org/10.1086/599556

48. Lewison, D. M. (1994). Retailing (5th ed.). New York: Macmillan College Publishing Company.

49. Lin, Y.-F., \& Yoon, S.-Y. (2015). Exploring the Effects of Lighting on Consumer Responses in a Retail Environment using 3D Walk-Through Animation. Archives of Design Research, 28(2), 5. https://doi.org/10.15187/ adr.2015.05.28.2.5

50. Liu, S. S., Melara, R., \& Arangarasan, R. (2007). The Effects of Store Layout on Consumer Buying Behavioral Parameters with Visual Technology. Journal of Shopping Center Research, 14(2), 63-72. Retrieved from http://connection.ebscohost.com/c/ articles/62247965/effects-storelayout-consumer-buying-behavioral-parameters-visual-technology

51. Luo, X. (2005). How does shopping with others influence impulsive purchasing? Journal of Consumer Psychology, 15(4), 288-294. https://doi.org/10.1207/ s15327663jcp1504_3

52. Ma, J.-Y., Liu, T., Li, X., \& Chen, Y.-W. (2017). The Impact of Background Music Rhythm on Impulsive Buying: Moderating Effect of Shopping Attitude. 2017 International Conference on Economics and Management Engineering (ICEME 2017), 1-6. https://doi.org/10.12783/dtem/ iceme2017/11757

53. Maheshwari, R., \& Verma, P. (2016, July 9). Retail companies seeing attrition rate for sales executives drop to $40-45 \%$ this year. The Economic Times Retrieved from http://search. ebscohost.com/login.aspx? direct=t rue \&db=bsu\&AN=118800665\&sit $\mathrm{e}=$ ehost-live

54. Mattila, A. S., \& Wirtz, J. (2001). Congruency of scent and music as a driver of in-store evaluations and behavior. Journal of Retailing, 77(2), 273-289. https://doi. org/10.7151/dmgt.1063

55. Mattila, A. S., \& Wirtz, J. (2008). The role of store environmental stimulation and social factors on impulse purchasing. Journal of Services Marketing, 22(7), 562-567. https://doi org/10.1108/08876040810909686

56. Mihic, M., \& Kursan, I. (2010). Assessing the situational factors and impulsive buying behavior: Market segmentation approach. Management, 15(2), 47-66. Retrieved from https:// www.researchgate.net/publication/285752364_Assessing_the_ situational_factors_and_impulsive_buying_behavior_Market_ segmentation_approach

57. Milliman, R. E. (1986). The Influence of Background Music on the Behavior of Restaurant Patrons. Journal of Consumer Research, 13(2), 286-289. Retrieved from https://www.jstor. org/stable/2489234?seq=1

58. Mitchell, M. R., \& Potenza, M. N. (2015). Importance of sex differences in impulse control and addictions. Frontiers in Psychiatry 6, 1-5. https://doi.org/10.3389/ fpsyt.2015.00024

59. Mohamad, M. S. (2015). Store Environment, Personality Factors and Impulse Buying Behavior in Egypt: The Mediating Roles of Shop Enjoyment and Impulse Buying Tendencies. Journal of Business and Management Sciences, 3(2), 69-77. Retrieved from https://www.researchgate. net/publication/331839370_Store_ Environment_Personality_Factors_and_Impulse_Buying_Behavior_in_Egypt_The_Mediating Roles_of_Shop_Enjoyment_and Impulse_Buying_Tendencies

60. Mohan, G., Sivakumaran, B., \& Sharma, P. (2013). Impact of store 
environment on impulse buying behavior. European Journal of Marketing, 47(10), 1711-1732. https://doi.org/10.1108/EJM-032011-0110

61. Moore, C. M. (2006). From Fiorucci to the guerrilla stores: Shop displays in architecture, marketing and communications. Oxford: Windsor Books.

62. Morrison, M., Gan, S., Dubelaar, C., \& Oppewal, H. (2011). In-store music and aroma influences on shopper behavior and satisfaction. Journal of Business Research, 64(6) 558-564. https://doi.org/10.1016/j. jbusres.2010.06.006

63. MSME-Development Institute. (2016). Karnataka State Industrial Profile 2015-2016. Retrieved from http://dcmsme.gov.in/dips/ state_wise_dips/state_profile_karnatka_11316.pdf

64. Muratore, I. (2016). Teens as impulsive buyers: what is the role of price? International Journal of Retail and Distribution Management, 44(11), 11661180. https://doi.org/10.1108/ IJRDM-08-2015-0120

65. NASSCOM. (2017). NASSCOM AT Kearney Reveal Karnataka IT Potential. Retrieved April 19, 2020 from Firstpost website: https:// www.firstpost.com/business/biztech/nasscom-at-kearney-revealkarnataka-it-potential-1866589. html

66. Nirushan, V. R., \& Nirushan, K. (2017). Impact of In-Store Environment Perception on Impulse Purchasing Behaviour at Supermarkets in Trincomalee District. Amity Journal of Marketing, 1(2), 29-43. Retrieved from https://amity.edu/UserFiles/ admaa/ecbf8Paper\%203.pdf

67. Oliver, R. L., \& Swan, J. E. (1989). Consumer Perceptions of Interpersonal Equity and Satisfaction in Transactions: A Field Survey Approach. Journal of Marketing, 53(2), 21-35. https:// doi.org/10.2307/1251411

68. Pandey, J. M. (2018). Not just women, men shop on impulse too: Survey. Retrieved from Times of India website: https://timesofindia. indiatimes.com/india/not-justwomen-men-shop-on-impulsetoo-survey/articleshow/65190769. $\mathrm{cms}$

69. Parboteeah, D. V. (2005). A Model of Online Impulse Buying: An Empirical Study. Washington State University.

70. Pornpitakpan, C., Yuan, Y., \& Han, J. H. (2017). The effect of salespersons' retail service quality and consumers' mood on impulse buying. Australasian Marketing Journal, 25(1), 2-11. https://doi. org/10.1016/j.ausmj.2016.12.003

71. Pradhan, V. (2016). Study on Impulsive Buying Behavior among Consumers in Supermarket in Kathmandu Valley. Journal of Business and Social Sciences Research, 1(2), 215-233. Retrieved from https://www.researchgate.net/ publication/327354814_Study_ on_Impulsive_Buying_Behavior_among_Consumers_in_Supermarket_in_Kathmandu_Valley

72. Prakash, G., Sahney, S., Kodati, S., \& Shrivastava, A. (2017). Gender effects on impulse buying behavior. Emerald Emerging Markets Case Studies, 7(7), 1-12. https://doi.org/10.1108/ EEMCS-05-2016-0075

73. PTI. (2019, December 18). India's apparel market to reach USD 85 bn by 2021: Report. ET Retail. Com. Retrieved from https://retail. economictimes.indiatimes.com/ news/apparel-fashion/apparel/indias-apparel-market-to-reach-usd85-bn-by-2021-report/72862772

74. Radder, L., \& Huang, W. (2008). High-involvement and low-involvement products: A comparison of brand awareness among students at a South African university. Journal of Fashion Marketing and Management, 12, 232-243. https://doi. org/10.1108/13612020810874908

75. Santos, E. B. A., \& Freire, O. B. D. L. (2013). The Influence of Music on Consumer Behavior. Independent Journal of Management \& Production, 4(2), 537-548. https://doi.org/10.14807/ ijmp.v4i2.111
76. Schaie, K. W., \& Heiss, R. (1964). Color and personality. Grune \& Stratton.

77. Schiffman, L. G., \& Wisenblit, J. L. (2015). Consumer Behavior (11th ed.). Delhi: Pearson India Education Services.

78. Sharma, P., Sivakumaran, B., \& Marshall, R. (2010). Impulse buying and variety seeking: A trait-correlates perspective. Journal of Business Research, 63(3), 276-283. https://doi.org/10.1016/j. jbusres.2009.03.013

79. Sharma, P., Sivakumaran, B., \& Marshall, R. (2014). Looking beyond impulse buying: A cross-cultural and multi-domain investigation of consumer impulsiveness. European Journal of Marketing, 48(5-6), 1159-1179. https://doi.org/10.1108/EJM-082011-0440

80. Singh, P., Katiyar, N., \& Verma, G. (2014). Retail Shoppability: The Impact Of Store Atmospherics $\&$ Store Layout On Consumer Buying Patterns. International Journal of Scientific \& Technology Research, 3(8), 15-23. Retrieved from https://www.ijstr.org/ final-print/aug2014/Retail-Shoppability-The-Impact-Of-StoreAtmospherics-Store-Layout-OnConsumer-Buying-Patterns.pdf

81. Smith, W. (1989). Trends in retail lighting: An intelligent design approach. International Journal of Retail and Distribution Management, 17(5), 30-32. https:// doi.org/10.1108/eb018424

82. Stern, H. (1962). The Significance of Impulse Buying Today. Journal of Marketing, 26(2), 59-62. Retrieved from https://www.jstor. org/stable/1248439? seq=1

83. Streiner, D. L., Norman, G. R., \& Cairney, J. (2015). Health Measurement Scales: A practical guide to their development and use (5th ed.). Oxford University Press.

84. Summers, T. A., \& Hebert, P. R. (2001). Shedding some light on store atmospherics: Influence of illumination on consumer behavior. Journal of Business Research, 54(2), 145-150. https://doi.org/10.1016/S01482963(99)00082-X 
85. Tulungen, C. E. (2013). Comparative Analysis of Impulse Buying based on Gender Differences. Jurnal EMBA, 1(4), 1349-1357. Retrieved from https://pdfs.semanticscholar.org/08c2/b6f8d7d5c1f61608394071a28366301d8c86. pdf

86. Turley, L. W., \& Milliman, R. E. (2000). Atmospheric effects on shopping behavior: A review of the experimental evidence. Journal of Business Research, 49(2), 193-211. https://doi.org/10.1016/ S0148-2963(99)00010-7

87. Ullal, M., \& Hawaldar, I. T. (2018). Influence of advertisement on customers based on the AIDA model. Problems and Perspectives in Management, 16(4), 285298. https://doi.org/10.21511/ ppm.16(4).2018.24

88. Ullal, M. S., Hawaldar, I. T., Mendon, S., \& Joseph, N. (2020). The effect of artificial intelligence on the sales graph in the Indian market. Entrepreneurship and Sustainability Issues, 7(4), 29402954. http://doi.org/10.9770/ jesi.2020.7.4(23)
89. Underhill, P. (2009). Why We Buy: The Science of Shopping. Simon \& Schuster. Retrieved from https:// www.amazon.com/Why-WeBuy-Shopping-Updated-Internet/ dp/1416595244

90. Virvilaite, R., Saladiene, V., \& Bagdonaite, R. (2009). Peculiarities of impulsive purchasing in the market of consumer goods. Engineering Economics, 2(62), 101-109. Retrieved from https:// pdfs.semanticscholar.org/b179/9d d38944e48a697917a028fb9572f2c 7a697.pdf

91. Vrechopoulos, A. P., O’Keefe, R. M., Doukidis, G. I., \& Siomkos, G. J. (2004). Virtual store layout: An experimental comparison in the context of grocery retail. Journal of Retailing, 80(1), 13-22. https://doi. org/10.1016/j.jretai.2004.01.006

92. Wallendorf, M., \& Arnould, E. J. (1988). "My Favorite Things": A Cross-Cultural Inquiry into Object Attachment, Possessiveness, and Social Linkage. Journal of Consumer Research, 14(4), 531-547. https:// doi.org/10.1086/209134
93. Williams, L. E., \& Bargh, J. A. (2008). Keeping one's distance: The influence of spatial distance cues on affect and evaluation. Psychological Science, 19(3), 302-308. https://doi.org/10.1111/ j.1467-9280.2008.02084.x

94. Yoo, C., Park, J., \& MacInnis, D. J. (1998). Effects of Store Characteristics and In-Store Emotional Experiences on Store Attitude. Journal of Business Research, 42(3), 253-263. https://doi.org/10.1016/S0148 2963(97)00122-7

95. Yu, C., \& Bastin, M. (2010). Hedonic shopping value and impulse buying behavior in transitional economies: A symbiosis in the Mainland China marketplace. Journal of Brand Management, 18(2), 105114. https://doi.org/10.1057/ bm.2010.32

96. Zhou, L., \& Wong, A. (2003). Consumer Impulse Buying and In-Store Stimuli in Chinese Supermarkets. Journal of International Consumer Marketing, 16(2), 37-53. https://doi. org/10.1300/J046v16n02_03 